ELORE (ISSN 1456-3010), vol. 20 - 2/2013.

Julkaisija: Suomen Kansantietouden Tutkijain Seura ry.

[http://www.elore.fi/arkisto/2_13/timonen.pdf]

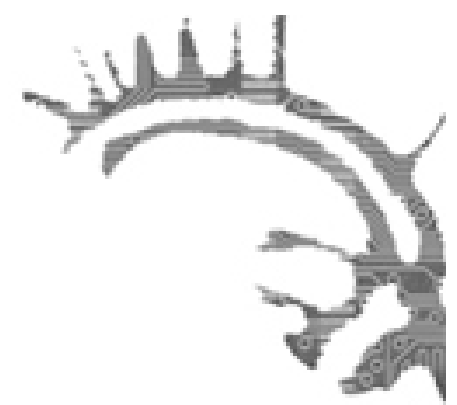

\title{
LECTIO
}

\section{IDENTITEETIN RAKENTUMINEN USKONNOLLISISTA YHTEISÖISTÄ IRTAUTUNEIDEN ELÄMÄNKERTOMUKSISSA}

\author{
Jukka Timonen
}

Lectio praecursoria Itä-Suomen yliopistossa 1.6.2013.

Asiat ovat niin kuin ne ovat, ja meistä tuntuu siltä miltä tuntuu. Tiedämme, että tämä tässä ja nyt on totta - tai ainakaan ei ole syytä väittää muuta. Näinhän arkijärki toimii. On luonnollista uskoa siihen, mikä tuntuu todelta ja minkä tietää olevan oikein. Tieto, tunteet ja havainnot voivat kuitenkin olla keskenään ristiriitaisia. Epämääräisyys voidaan usein sivuuttaa johonkin rajaan asti, mutta se voi myös johtaa todellisuuskäsityksen ja oman minuuden perusteiden murtumiseen. Uskonnollisista yhteisöistä irtautuvat henkilöt voivat kokea tällaisen murtumisen ja siitä seuraavan tarpeen määritellä perusasiat uudelleen.

Sisäisen ja absoluuttisen todellisuuden suhde ja uskomusten oikeutus ovat olleet aina filosofian peruskysymyksiä. Uskonnollisesta yhteisöstä irtautuvalle ne eivät kuitenkaan ole akateemista puuhastelua vaan ongelma, jonka ratkaisemisesta riippuu sekä oma paikka ikuisuudessa että tämänhetkinen sosiaalinen todellisuus. Tuhoudunko minä, jos maailma joskus loppuu, ja ketkä voivat olla läheisiäni tänään?

Yksilön todellisuutta koskevat käsitykset eivät ole aina koherentteja. Ne voivat jakautua erilaisille tiedon vyöhykkeille ja usein riittävää on se, että ydin on selkeä. Tässä nojaudun etenkin Alfred Schützin, Peter Bergerin ja Thomas Luckmannin esittämiin käsityksiin todellisuuden sosiaalisesta rakentumisesta. (Berger\&Luckmann 1994; Ber- 
Jukka Timonen: Identiteetin rakentuminen

ger 1973; Schütz 1970; Schütz\&Luckmann 1973.) Tästä näkökulmasta katsottuna uskonnollisen yhteisön jäseneksi syntynyt omaksuu yhteisön maailmankatsomuksen ensisijaisena käsityksenä maailmasta. Lapsi voi alusta asti oppia, että ulkopuolista maailmaa pitää varoa, totuus on vain omassa yhteisössä ja yhteisöön kuulumattomat eivät pelastu. Aikuisina yhteisöihin liittyvät voivat puolestaan joutua kieltämään aikaisemman todellisuutensa.

Selvitän tutkimuksessani, mitä uskonnollisista yhteisöistä irtautuvat kokevat ja kuinka he rakentavat ymmärrettävän kuvan itsestään ja elämästään. Yksilön on sijoitettava muutokset ja muutosta vastustavat tekijät tulkintaansa itsestään ja maailmasta. Yhteisöt ovat kehyksiä, joiden vaikuttamina elämän tapahtumille annetaan merkityksiä. Niiden ylläpitämät todellisuuskäsitykset voivat olla sisäisesti johdonmukaisia, mutta keskenään ristiriitaisia. Millaista on siirtyminen olemassaolon perusteita määrittelevästä kehyksestä toiseen? Elämää jäsennetään kertomalla siitä. Irtautujien elämänhistorialliset haastattelut, joista olen muodostanut tutkimusaineistoni, ovat samalla identiteettikertomuksia, joissa haastateltavat määrittelevät itseään suhteessa aikaan, elämäntapahtumiin ja toisiin ihmisiin.

Ymmärrän identiteetin muuttuvana ja monitasoisena yksilön käsityksenä itsestään. Siihen kietoutuu vuorovaikutuksessa syntyvä toisten käsitys yksilöstä. Identiteetti ilmaisee itsensä kertomuksessa, joka on kokemusten, toiveiden ja olosuhteiden leikkauspinta. Siinä perustellaan ja oikeutetaan sekä koettua että toivottua minää. Uskonnollinen identiteetti on yksi identiteetin osa-alueista: määrittelen sen käsitykseksi, jota yksilö rakentaa suhteessa hänelle relevantteihin uskonnon määritelmiin ja ilmentymiin.

Uskonnollisia käsityksiä ei voi todistaa suuntaan eikä toiseen tavalla, jonka kaikki hyväksyisivät. Lisäksi yksilön yhteisössä ja sen ulkopuolella kohtaamat sosiaaliset maailmat vetävät eri suuntiin ja rakentuvat erilaisille itsestäänselvyyksille. Irtautumisprosessit saavat alkunsa, kun yksilö havaitsee todellisuuskäsitysten ristiriidan, mutta vanhan purkaminen, osittainen säilyttäminen, uuden omaksuminen ja kaiken yhteen sovittaminen ei ole suoraviivaista etenemistä. Identiteetissä on monia tasoja, ja uskonnossa on monta ulottuvuutta. Nämä kohtaavat toisensa prosessissa ja muuttuvat eri aikaan. Todellisuus ei aina tunnu todelta.

Jäsenyys yhteisössä on sijoitettava osaksi elämänhistoriaa. Se ei katoa, ja kertomus ei pääty. Siksi on luontevampaa puhua irtautujista kuin irtautuneista. On tärkeätä erottaa yhteisöstä eroaminen ja irtautuminen. Ensimmäinen on tapahtuma, jossa luovutaan muodollisesta jäsenyydestä. Jälkimmäinen on prosessi, jossa tapahtumat saavat merkityksiä.

Tutkimukseeni on osallistunut 15 ihmistä, joista osaa olen haastatellut useita kertoja vuosien aikana. Olen nähnyt, kuinka tulkinnat muuttuvat ajan kuluessa ja eri konteksteissa, kuten kuuluttaessa eri yhteisöihin tai kun irtautuja saa jälkeenpäin uutta tietoa menneisyydestään. Tutkittavien taustat ovat erilaisia. Olisi voinut olla helpompaa keskittyä yhdestä yhteisöstä lähteneisiin, mutta silloin olisivat jääneet näkemättä toisaalta kokemusten monimuotoisuus ja toisaalta yhdistävät piirteet, jotka eivät riipu yhteisörajoista.

Aihe on arkaluonteinen ja eettisesti vaativa. Olen joutunut kysymään, onko aiheen tutkiminen oikeutettua ja onko siitä hyötyä tutkittaville. Olen ollut kahden toiveen välissä. Tutkittavat ovat puhuneet avoimesti ja toivoneet, että julkinen tieto auttaisi muita irtautujia. Samalla he ovat halunneet suojella yksityisyyttään - jotkut enemmän kuin 
toiset. He eivät halua, että heidät määritellään julkisesti menneisyyden kautta tavalla, johon he eivät voi itse vaikuttaa.

Olen halunnut kirjoittaa oikeudenmukaisesti myös yhteisöistä. Korostan, että irtautujien kertomukset eivät ole neutraaleja ja yleistettäviä yhteisökuvauksia. Kertomukset käsittelevät kuitenkin kiistatta kokemuksia, jotka ovat vaikeita. En ole halunnut laimentaa niitä. Kertomuksissa arvostellaan yhteisöjen vallankäyttöä, roolivaatimuksia ja oman totuuden ylistämistä, jonka vuoksi värryyksiä ei tunnisteta eikä korjata. Kertomuksissa puhutaan ruumiillisesta kurituksesta, väkivallasta ja hyväksikäytöstä. Irtautujat eivät väitä, että yhteisöt hyväksyisivät räikeimmät vääryydet, mutta ilmapiiri voi altistaa niille. Kertomukset eivät kumoa sitä, että yhteisöissä on myös tyytyväisiä jäseniä.

Irtautuminen on aiemmin nähty etenkin amerikkalaisen uususkonnollisuuden kautta. Yleinen mielikuva on ollut eristäytynyt kultti, jonka karismaattinen johtaja pitää jäseniä vallassaan ja kenties maailmanlopun odotuksessa. Irtautumista on pidetty vaikeana, koska aivopesu ja informaation rajoittaminen estävät jäseniä tekemästä omia päätöksiä. Suomessa irtautuminen on nähty usein uskonnon uhriksi joutumisena. Nimitys on lähtöisin Uskontojen uhrien tuki -yhdistyksestä, mutta nykyisin alkusointuinen "uskonnon uhri" on suorastaan yleisnimitys yhteisöstä eronneelle. Irtautuminen on nähty kriisinä ja usein seurauksena hengellisestä väkivallasta. Kriisiluonne tulee vahvasti esiin myös omassa aineistossani, mutta kaikki irtautumiskokemukset eivät ole kokijoiden mielestä kriisejä. Joskus irtautuminen voi merkityksellistyä irtautumiseksi vasta myöhemmissä elämäntulkinnoissa.

Käsitykset kulttien vaarallisuudesta ovat suodattuneet suomalaisiin käsityksiin uskonnon uhreista. Ne eivät suoraan kuvaa tutkimukseen osallistuneiden kokemuksia, mutta ne muodostavat tarinavarannon, josta irtautujat saavat aineksia oman elämänsä jäsentämiseen. He etäistävät itseään käsityksestä, jonka mukaan irtautujat ovat väistämättä ja lopullisesti uhreja. Uhriksi tunnustautuminen voi olla yksi identiteettikertomuksen vaihe. Uhrius on irtautumiskeskustelun emansipatorinen ulottuvuus - merkitysten tiivistymä, jonka kautta ongelmia voidaan käsitellä.

Olen jakanut tutkittavat jäseniksi kasvatettuihin ja omasta valinnastaan liittyneisiin. Tämä jako nousi aineistosta itsestään ja oli tutkimusasetelmassani merkittävin taustatekijä. Identiteettiprosessin näkökulmasta se yhdisti enemmän kuin se, mihin yhteisöön irtautuja on kuulunut. Identiteetin yhtenäisyyttä rakentavia elementtejä löytyi esimerkiksi kertomusten alkutiloista. Yhteisön jäsenyyttä edeltävään aikaan ei voi palata, mutta irtautujille on ollut tärkeätä löytää jotain, mikä on ollut olemassa ennen jäsenyyttä, kuten lapsuuden uskonnollisuus. Jäseniksi kasvatetuilla ei ole jäsenyyttä edeltäviä kokemuksia, mutta hekin ovat löytäneet lapsuudestaan asioita, joiden merkitys ei rakennu yhteisöstä käsin ja joita he voivat pitää merkittävinä nyt.

Irtautujat joutuvat oikeuttamaan ratkaisunsa itselle ja muille. Olennaista kertomuksissa on se, millainen painoarvo omalle subjektiivisuudelle annetaan. Kertomusnäkökulmasta tarkasteltaessa William Jamesin määritelmät uskonnollisille kokemuksille yli sadan vuoden takaa osoittautuivat päteviksi. Uskottavalla uskonnollisella kokemuksella on kokijalleen auktoriteettiluonne. Jos ihmisten muodostama yhteisö opettaa, että irtautujat joutuvat helvettiin tai raukeavat tyhjiin maailman loppuessa, oma subjektiivinen ja empiirinen kokemus Jumalan kohtaamisesta on yksilölle itselleen vahvin osoitus siitä, ettei 
tuomiota tarvitse pelätä. Näin kokemus voi vahvistaa nykyisyyttä. Toisaalta yhteisössä alun perin vahvistavana koettu uskonnollinen kokemus voi saada uuden merkityksen eron jälkeen. Tulkinta voi muuttua kielteiseksi ja ahdistavaksi. Kokemukset pysyvät kuitenkin todellisina. Eroaminen yhteisöstä, joka antoi kokemuksille alkuperäisen merkityksen, ei saa kieltämään niitä. Niille rakennetaan uuden todellisuuden mukainen selitys ja merkitys.

Yhteisöt voivat sijoittaa entiset jäsenensä kategoriaan, johon liitetään negatiivisia merkityksiä tavalla, joka ylittää yksittäisen entisen jäsenen ominaisuudet. Entiset jäsenet voidaan määritellä Saatanan kanssa liittoutuneiksi luopioiksi, jotka kieltävät totuuden ja etsivät vain omaa etuaan. Irtautujat joutuvat vastustamaan tätä luopiodiskurssia, mutta heillä ei välttämättä ole yhteisöllistä tukea ratkaisuilleen. Tässä irtautuminen eroaa yhteisöön liittävästä kääntymisestä: kääntyjällä on ratkaisulleen yhteisöllinen tuki, ja yhteisö myös tarjoaa muutokselle ilmaisutavan.

Internetissä syntyvä irtautujien keskinäinen yhteisöllisyys muuttaa kuitenkin tätä asetelmaa. Luopiodiskurssia vastustetaan luomalla yhteisön kielelle käänteismerkityksiä. Oppien virheellisyydestä etsitään todisteita, ja sosiaalisia käytäntöjä arvostellaan ulkopuolisen näkökulmasta, mutta sisäpuolisen asiantuntemuksella. Samalla syntyy yhteisiä perusteluja irtautumiselle. Luopio ja uskonnon uhri ovat kategorioita, joiden määrittelemisen vallasta kamppaillaan ja joihin yksilöt haluavat kuulua vain oman määrittelynsä kautta.

Voi olla helpompaa osoittaa toisille ihmisille menneisyyden epäuskottavuus kuin nykyisyyden uskottavuus. Uuden todellisuuden oikeutuksesta vakuuttuminen on tärkein ja samalla vaikein kysymys, johon ei lopulta löydetä vastausta, joka olisi kaikille kiistaton. Epävarmuus sijoitetaan metatason selitysten sisään. Tapahtumat voidaan tulkita uskon kirkastumiseksi, jossa usko ei ole muuttunut, mutta sopimaton yhteisö on vaihtunut toiseksi. Toista kokoavaa selitystä nimitän väistämättömyyden ymmärtämiseksi: menneisyyden olosuhteissa ei mitenkään olisi voinut käydä toisin. Usko ei välttämättä kadonnut, koska sitä ei ollutkaan; uskonnollisuus johtui vain sosiaalisen todellisuuden vaihtoehdottomuudesta. Kolmatta toistuvaa selitystä nimitän uskon löytämiseksi. Siinä yksilö näkee vastuun itsessään ja tulkitsee harhailleensa hyvän ja pahan rajan väärällä puolella, josta oikean uskon löytäminen pelasti.

Irtautujien identiteettikertomuksissa ajan kuluminen ei johda tulkintojen yksinkertaistumiseen. Ajan kuluessa vahvistuu kyky nähdä, kuinka monenlaiset tekijät ovat muovanneet menneisyyttä. Subjektiivisuuteen luottaminen vahvistuu. Uskonnollisiksi tunnustautuvat irtautujat kertovat, kuinka suhde korkeampaan voimaan on nyt suora. Väliin ei tarvita ihmisten auktoriteettia. Ateismiin päätyneet irtautujat kertovat samansuuntaisesti, kuinka nykyisyys rakentuu omista lähtökohdista. Oppien epäjohdonmukaisuuteen, logiikkaan ja yleisiin eettisiin normeihin tukeutuvista perusteluista huolimatta perimmäinen perustelu nykyisyydelle on se, että nykyisyys tuntuu enemmän oikealta. Kertomuksissa pidetään vapauttavana oivalluksena sitä, että ehdotonta varmuutta ei voi olla, ja sellaista ei tarvitakaan. Subjektiivinen tunne toimivuudesta, jota itselle sopiva traditio tukee, on tavoittelemisen arvoinen tila. Tulkinta toimivasta tästä hetkestä voi muuttua myöhemmin. Menneisyys on aina sijoitettava uuteen nykyisyyteen. 
Jukka Timonen: Identiteetin rakentuminen

TIMONEN, JUKKA 2013: Todellisuudesta toiseen. Identiteetin rakentuminen uskonnollisista yhteisöistä irtautuneiden elämänkertomuksissa. Kultaneito XII. Joensuu: Suomen Kansantietouden Tutkijain Seura.

\section{KirJallisuUs}

BERGER, PETER L. \& LUCKMANN, THOMAS 1994: Todellisuuden sosiaalinen rakentuminen. Helsinki: Gaudeamus.

BERGER, PETER L. 1973: The Social Reality of Religion. Harmondsworth: Penguin Books Ltd.

SCHÜTZ, ALFRED 1970: On phenomenology and social relations. Selected writings. Edited and with an introduction by Helmut R. Wagner. Chicago: The University of Chicago Press.

SCHÜTZ, ALFRED \& LUCKMANN, THOMAS 1973: The Structures of the LifeWorld. Evanston: Northwestern University Press.

Filosofian tohtori Jukka Timonen työskentelee arkistotutkijana Suomalaisen Kirjallisuuden Seuran Joensuun perinnearkistossa. 